\title{
The impact of work-life balance on employees' job satisfaction and turnover intention; the moderating role of continuance commitment
}

\author{
Marjan Fayyazi, Farshad Aslani* \\ Faculty of Management, University of Tehran, Tehran, Iran \\ *Email address: Aslanifarshad@yahoo.com
}

Keywords: Work-life balance; Turnover intention; Job satisfaction; Continuance commitment

\begin{abstract}
Work-life imbalance has several negative impacts on employees' attitudes and behaviors and consequently influences organizations' performance and effectiveness. The purpose of this article is to investigate the impact of work-life balance (WLB) on employees' job satisfaction and turnover intention. Moreover, we study the moderating role of continuance commitment on job satisfaction turnover intention relationship. Regression analysis was used to analyze the data collected from 265 questionnaires completed by employees in an Iranian industrial company. The findings supported that WLB has a significant positive relationship with job satisfaction, and a significant negative relationship with turnover intention. Besides, job satisfaction fully mediates the WLB - turnover intention relationship. The main contribution of the paper is that we found continuance commitment moderates the relationship between job satisfaction and turnover intention. Therefore, employees with low levels of WLB and job satisfaction do not necessary have high turnover intention, unless they have low continuance commitment.
\end{abstract}

\section{INTRODUCTION}

Work-life balance has become one of the important challenges of today's organizations and employees [1] and it has been the focus of several researches in both academy and practice. New technologies and customers' demands have changed the working patterns of the past and have challenged individuals' work-life balance. Today the distinct traditional borders between work and personal life have become blurred [2]. New communication technologies such as email don't let the employees completely detach from work when they are at home or with their families [3]. In addition, changes in the demography of workforce and increasing number females workers, has led to more work-life conflict during the past decades [4].

Work-life balance is defined as satisfaction and good functioning at work and at home with a minimum of role conflict [5]. Greenhaus et al (2003) defined work-life balance as "the extent to which an individual is equally engaged in - and equally satisfied with - his or her work role and family role" [6]. In contrast work-life conflict is defined as a lack of fit between employees and their life responsibilities and the goals of their organization [7]. Therefore, in some studies work-life balance is considered as the absence of work-life conflict [8]. Although work-family balance and work-life balance are used in interchangeably in the literature, work-life balance refers to a more comprehensive concept.

Work-life balance leads to negative outcomes such as increased performance [9-10] and high affective commitment [11]. On the contrary work-life imbalance results in negative attitudes and behaviors such as job burnout, emotional exhaustion [12] and decreased commitment [13]. One of the consequences of work-life imbalance is turnover intention. Employees' turnover results in decreased performance and efficiency of the organizations [14]. Besides, work-life imbalance is associated with job dissatisfaction which in turn leads to negative outcomes such as workplace deviance [15] and low performance [16].

However, researchers believe that the influence of work-life (im)balance on employees and organizations are yet to be identified [8] [17]. Moreover most of the studies about WLB are conducted in western countries. Due to the different cultural and economic situation in western and 
non-western countries the generalization of western based ideas to non-western countries is controversial [18-19]. Additionally, due to international sanctions, Iran's economy has encountered some serious challenges. Both men and women in families have to work hard and many employees prefer to work overtime in order to increase their income. On the other hand, several companies have released some of their workforce in order to manage the expenses, which has resulted in more workload imposed on the remaining employees and consequently more work-life conflict.

In this article we investigate the impact of WLB on employees' job satisfaction and turnover intention. Since job satisfaction is one of the important antecedents of turnover intention, we hypothesize that job satisfaction mediates the relation between WLB and turnover intention. In addition we assume that employees with high continuance commitment have lower intention to quit even if they suffer from work-life conflict or job dissatisfaction. Therefore in this study we hypothesize that continuance commitment moderates the job satisfaction - turnover intention relationship in a way that the higher the continuance commitment is, the lower the turnover intention is. The conceptual model of the research is indicated in figure 1.

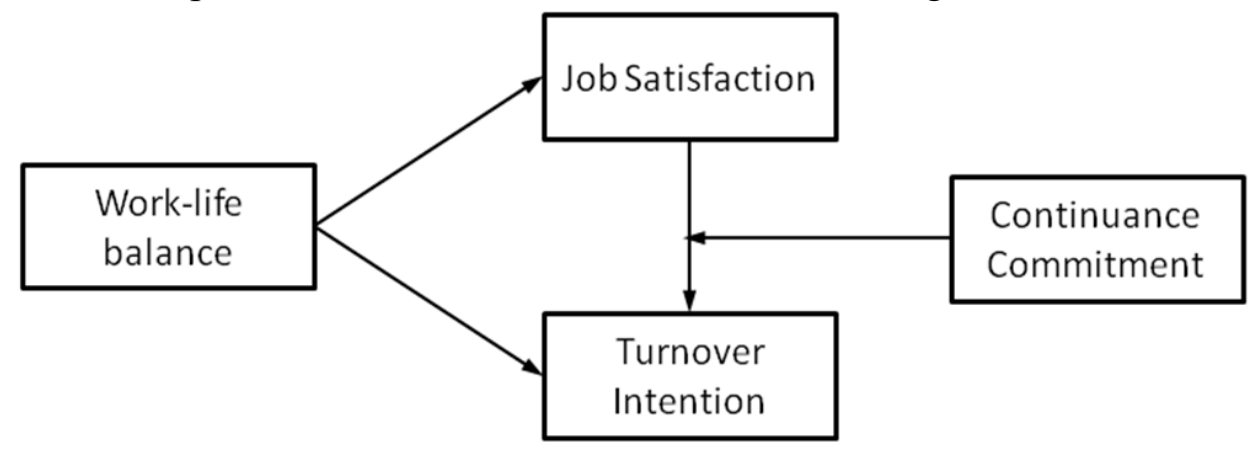

Figure 1. The conceptual model of the research

\section{LITERATURE REVIEW}

\subsection{WLB}

WLB refers to $g$ equal investment in work and non-work domains of life. Greenhaus et al (2003) argue that there are three dimensions of WLB; (1) time balance which is allocating equal time to work and family, (2) involvement balance defined as mental involvement with work and family issues and (3) and satisfaction balance which is equal satisfaction with family and work[6].

WLB is a continuum and at one end the imbalance is in favor of family and at the other end the imbalance is in favor of work. WLB, which refers to equal commitment and time allocation to work and personal life issues, is considered to be in the middle of the continuum. However, it was found that individuals with high WLB do not necessarily experience a higher quality or happier life than the one with work-life conflict. The study by Greenhaus et al. (2003) revealed that the ones experiencing imbalance in favor of their family are happier than individuals who stroke balance between their work and life [6].

Today many organizations implement family-friendly initiatives to assist their employees balance their work and life. These initiatives are categorized into two sets cultural and structural support. Structural support initiatives are such as flexible schedules and work arrangements, teleworking, job redesign, decreased workloads, and changing the policies about absenteeism or parental leave. Cultural supports are such as supportive supervisors or organizational climate[20].

\subsection{WLB and job satisfaction}

Job satisfaction is "a positive feeling about a job resulting from an evaluation of its characteristics" [21]. Job satisfaction has been the focus of several studies and numerous factors are identified as antecedents of job satisfaction in the literature. One of the important antecedents of job satisfaction is work-life balance. However, studies examining the relationship between work-life 
balance and job satisfaction usually focus on the impact of lack of work-life balance or work-family conflict on job satisfaction. It's been confirmed that employees who suffer from conflict between their work and non-work issues, have lower levels of both job and life satisfaction [22-23]. In a study on bus drivers it was found that work and non-work imbalance was the main reason for employees' job dissatisfaction [24]. Other researchers have also confirmed the negative relationship between work-family conflict and employees' job satisfaction [25-26]. Therefore we hypothesize as:

H1. Work-life balance is positively related to job satisfaction.

\subsection{WLB and turnover intention}

Work-life balance considered to be an important factor in employees' intention to quit. Worklife imbalance has a more important role in employees' turnover intention comparing to factors such as management behavior towards the employees or the amount of pay [24]. There is no value to the amount of pay an employee receives when he has no time out of the organization to spend the money [14]. The happier the employees are in their personal life, the happier they are at work [27]. It is confirmed that work life balance has a negative impact on turnover intention [14]. Employees who perceive higher levels of balance in their work and life have lower intention to quit [27]. On the other hand, studies have confirmed that work-family conflict increases employees' intention to quit [25]. Thus, it is hypothesized as:

H2. Work-life balance is negatively related to turnover intention.

\subsection{Job satisfaction and turnover intention}

Turnover intention is the possibility that an employee leaves their position in near future [28]. Several factors might influence employees' turnover intention such as ethical leadership and climate [29], commitment [30], psychological contract breach [31], and organizational satisfaction [32]. Although different factors influence employees' turnover intention, job satisfaction is the main reason leading to turnover intention [33]. Several studies have confirmed the negative relation of job satisfaction and turnover intention. [34-36]. Employees with low job satisfaction decide to quit the organization in the hope of finding a more satisfactory job.

In most studies on turnover intention, job satisfaction is identified as one of the most important antecedents of turnover intention. In addition considering the positive relationship between WLB and JS, and negative relationship between WLB and turnover intention, we assume that the impact of WLB on turnover intention is through the mediating role of job satisfaction. It means that employees experiencing work-life conflict have high intention to quit because they lose their job satisfaction. Thus, we offer the two following hypotheses:

H3. Job satisfaction is negatively related to turnover intention. intention.

H4. Job satisfaction mediates the relationship between work-life balance and turnover

\subsection{Moderating role of continuance commitment}

As it was previously noted, employees with low job satisfaction as the result of work life imbalance, have high intention to quit. However, the authors of this article assume that employees who perceive they have little or no job opportunities outside the organization don't have high intention to quit. In current economic situation of Iran, many employees experience work-life balance and consequently have low job satisfaction. However, due to lack of job alternatives and the fear of losing the present or potential job situation in the current company, they remain in the company.

Lack of job alternatives is the main element of continuance commitment. Continuance commitment reflects the perceived costs associated with leaving and is based on two elements 
which are (1) the magnitude of investments that employees make and (2) perceived lack of alternatives [37]. In contrast to affective commitment by which employees desire to stay, continuance commitment binds the employees to the organization because they have limited alternatives [38].

The negative relation between continuance commitment and turnover intention has been confirmed in several studies [39-40]. Therefore, it is expected that employees with low job satisfaction have higher turnover intention if they have low continuance commitment. Hence, we posit our hypothesis as:

H5. Continuance commitment moderates the relation between job satisfaction and turnover intention as employees with high continuance commitment have lower turnover intention and employees with low continuance commitment have higher turnover intention.

\section{METHODOLOGY}

\subsection{Respondents}

The sample of this study consists of 265 employees working in an Iranian industrial company. Of the 300 questionnaires distributed, 265 valid questionnaires were obtained. The majority of respondents $(91.2 \%)$ were males and $8.8 \%$ were female. $62.9 \%$ of participants aged between 26 to $35,18.2 \%$ aged between $36-45,17.4 \%$ were 25 and below and $1.5 \%$ were over 45 . Of the respondents $77.7 \%$ were single and $22.3 \%$ were married.

\subsection{Measures}

All variables of the research were measured using standard questionnaires. We used 5 point Likert scale in which 5 indicated totally agree and 1 indicated totally disagree. Work-life balance was assessed using the questionnaire developed by Chen and Farh (2000) and adapted by Huang et al (2007) [41], turnover intention was measured using questionnaire developed by Colarelli (1984) [42]. We used the questionnaire designed by cellucci (1978) and later adapted by fu et al (2011) [43] to measure job satisfaction. Finally, continuance commitment was assessed using the questionnaire developed by Jaros et al (1993) [44]. The internal reliability of all items are over 0.7 (see table 1$)$.

\section{DATA ANALYSIS}

The means, standard deviation, correlations, and internal reliability of the research variables are shown in table 1. In order to test the mediating relationship three steps are recommended. First, the independent variable must have a significant relationship with the dependant variable. Second, there should be significant relationship between independent variable and the mediator. Third, after entering the mediator the significance of relationship between independent and dependent variables should change. If it becomes insignificant the relationship is fully mediated and if it decreases the relationship is partial mediation [45].

Table 1. Means, standard deviation, correlations, and internal reliability of the variables

\begin{tabular}{|c|c|c|c|c|c|c|}
\hline variable & Mean & SD & WLB & $\begin{array}{c}\text { Job } \\
\text { Satisfaction }\end{array}$ & $\begin{array}{c}\text { Continuance } \\
\text { commitment }\end{array}$ & $\begin{array}{c}\text { Turnover } \\
\text { Intention }\end{array}$ \\
\hline WLB & 1.73 & 12.42 & 0.81 & & & \\
\hline Job Satisfaction & 2.27 & 11.65 & $0.51^{* *}$ & 0.73 & & \\
\hline Continuance commitment & 1.96 & 6.12 & 0.06 & -0.07 & 0.91 & 0.85 \\
\hline Turnover Intention & 3.27 & 7.23 & $-0.38^{* *}$ & $-0.74^{* *}$ & $0.37^{* *}$ & \\
\hline \multicolumn{7}{|c|}{ Note: *P value $<0.05 ; * *$ value $<0.01$} \\
Diagonal represents Cronbach Alpha (Threshold $=0.7) ;$ Below the diagonal the correlations are \\
reported.
\end{tabular}


Table 2 shows the results of these three steps. The results of step 1 demonstrate the significant negative relationship between WLB and turnover intention, thus H2 is supported. The results of step 2 indicate that there is a positive significant relationship between WLB and job satisfaction, hence $\mathrm{H} 1$ is also supported. The results of step 3 show that job satisfaction is significantly and positively associated with turnover intention. Moreover, by entering job satisfaction the relationship between WLB and turnover intention becomes insignificant. Hence $\mathrm{H} 3$ and $\mathrm{H} 4$ are supported. In addition the results of three steps indicate that the 3 conditions for full mediation are met and job satisfaction fully mediates the WLB - turnover intention relationship.

Table 2. Regression results of the mediated model

\begin{tabular}{|c|c|c|c|c|c|}
\hline Step & Variable & $\beta$ & $\mathrm{R}^{2}$ & $\mathrm{R}^{2}$ (Adj.) & $\mathrm{F}$ \\
& & & & & \\
\hline 1 & WLB $\rightarrow$ Turnover intention & $-0.38^{* *}$ & 0.22 & 0.18 & $51.8^{* *}$ \\
\hline 2 & WLB $\rightarrow$ Job satisfaction & $0.42^{* *}$ & 0.28 & 0.26 & $79.3^{* *}$ \\
\hline 3 & WLB $\rightarrow$ Turnover intention & -0.16 & 0.51 & 0.47 & $82.4^{* *}$ \\
\cline { 2 - 3 } & Job satisfaction $\rightarrow$ Turnover intention & $-0.48^{* *}$ & & & \\
\hline \multicolumn{4}{|c|}{ Note: *P value $<0.05 ; * *$ P value $<0.01$} \\
\hline
\end{tabular}

Table 3 demonstrates the results of regression analysis we conducted to test the moderating relationship. The results indicate that both job satisfaction and continuance commitment are significantly associated with turnover intention. To test the moderating effect, we analyzed the interaction of job satisfaction and continuance commitment on turnover intention. As it is seen in table 3, the interaction is also significant and therefore $\mathrm{H} 5$ is supported and continuance commitment moderates the relationship between job satisfaction and turnover intention.

Table 3. Regression results of the moderated model

\begin{tabular}{|c|c|c|c|c|c|c|}
\hline Variable & $\beta$ & $\mathrm{R}^{2}$ & $\begin{array}{l}\mathrm{R}^{2} \\
\text { (Adj.) }\end{array}$ & $\Delta \mathrm{R}^{2}$ & $\mathrm{~F}$ & $\mathrm{df}$ \\
\hline JS $\rightarrow$ Turnover Intention & $-0.51^{* *}$ & & & & & \\
\hline $\mathrm{CC} \rightarrow$ Turnover Intention & $-0.23 * *$ & & & & & \\
\hline $\mathrm{JS} \times \mathrm{CC} \rightarrow$ Turnover Intention & $-0.39^{* *}$ & 0.48 & 0.46 & $0.4^{* *}$ & $8.73 *$ & 1,198 \\
\hline
\end{tabular}

\section{DISCUSSION}

Work-life imbalance has several negative impacts on employees' attitude and behavior and consequently results in decreased organizational performance. Therefore, WLB has been the focus many researches and organizational initiatives. In this study we examined the relationship between WLB, job satisfaction and turnover intention. In addition we contributed to the literature by showing that continuance commitment moderated the relationship between job satisfaction and turnover intention.

Along with previous researches (25) (23), we found that WLB is positively associated with job satisfaction. Work-life conflict influences employees' job attitudes and consequently leads to lower levels of job satisfaction. We also found that WLB has a negative relationship with turnover intention. this finding is in line with studies of (14) (27)When employees experience work-life conflict they decide to quit the current job and find a job which helps them to strike a balance between work and non-work issues. Additionally, we contributed to the literature of the subject by 
representing that job satisfaction fully mediates the relationship between WLB and turnover intention. This implies that work-life conflict influences employees' job attitudes and they lose interest in their job. Hence, individuals with low levels of job satisfaction decide to quit their current job in the expectation of finding a job which is more satisfactory and also allows them for a better work-life balance.

The main contribution of this paper was to investigate the moderating role of continuance commitment in the relationship between job satisfaction and turnover intention. Base on the findings, employees with work-life conflict and decreased job satisfaction have high intention to quit, only if they have low levels of continuance commitment. In fact, employees perceiving limited job alternatives are less likely to have high intention to quit, even if they suffer from work-life imbalance or job dissatisfaction. The implication of this finding for managers is that employees' low intention to quit, cannot necessarily be interpreted as they are satisfied with their job or/and have a balanced work-life. Most of the individuals suffering from work-life conflict or job dissatisfaction have to stay with the organization, simply because they have no other options. Therefore, it is suggested that managers use periodic tests to assess employees' level of job satisfaction. It is also suggested that managers try to identify employees' work-life conflict issues through individual or group meetings. In case of identifying work-life conflict and job dissatisfaction, managers need to implement initiatives that assist employees balance their work and non-work domains of their life.

Studies have confirmed the effectiveness of family-friendly policies in assisting employees balancing their work and life. Therefore, the negative consequences of WLB suggest managers should design and execute family friendly policies such as flexible working hours, logical workload, and teleworking. Moreover, organization and supervisor supports are important factors in helping employees manage their work and non-work domains of life.

\section{References}

[1] Sturges, J., \& Guest, D. Working to live or living to work? Work/life balance early in the career . Human Resource Management Journal, Vol 14, no 4, pp. 5-20 (2004).

[2] Woodward, D. Work-life balancing strategies used by women managers in British "modern" universities. Equal Opportunities International, Vol. 26 No. 1, pp. 6-17, (2007).

[3] Waller, A. D., \& Ragsdell, G. The impact of e-mail on work-life balance. Aslib Proceedings: New Information Perspectives, Vol. 64 No. 2, pp. 154-177, (2012).

[4] Boyar, S. L., Maertz.Jr, C. P., \& Pearson, A. W. The effects of work-family conflict and family-work conflict on nonattendance behaviors. Journal of Business Research, 58 (7), pp. 919- 925, (2005).

[5] Clark, S. C. Work/family border theory: a new theory of work/family balance. Human Relations , 53, 747-770, (2000).

[6] Greenhaus, J. H., Collins, K. M., \& Shaw, J. D. The relation between work-family balance and quality of life. Journal of Vocational Behavior, Vol. 63, Iss. 3, pp. 510-531, (2003).

[7] Becker, B. E., \& Huselid, M. A., High performance work systems and firm performance: a synthesis of research and managerial implications. Research in Personnel and Human Resource Management, Vol. 16, pp. 53-101, (1998).

[8] Kim, H. K., Work-Life Balance and Employees' Performance: The Mediating Role of Affective Commitment. Global Business and Management Research: An International Journal , Vol. 6, No. 1, (2014).

[9] Harrington, B., \& Ladge, J., Work-Life Integration: Present Dynamics and Future Directions for Organizations. Organizational Dynamics , 38(2):148-157, (2009). 
[10] Parkes, L. P., \& Langford, P. H., Work-life balance or work-life alignment? A test of the importance of work-life balance for employee engagement and intention to stay in organizations. Journal of Management and Organization , 14, 267-284, (2008).

[11] Muse, L., Harris, S. G., Giles, W. F., \& Feild, H. S., Work-life benefits and positive organizational behavior: Is there a connection? Journal of Organizational Behavior, vol 29 pp171-192, (2008).

[12] Lingard, H. C., Yip, B., Rowlinson, S., \& Kvan, T., The experience of burnout among future construction professionals: a cross-national study. Construction Management and Economics, Vol. 25, Iss. 4, PP. 345-357, (2007).

[13] Akintayo, D. I., Work-family role conflict and organizational commitment among industrial workers in Nigeria. Journal of Psychology and Counseling, Vol. 2(1), pp.1-8, (2010).

[14] Surienty, L., Ramayah, T., Lo, M.-C., \& Tarmizi, A. N., Quality of Work Life and Turnover Intention: A Partial Least Square (PLS) Approach. Social Indicators Research , 405-420, (2014).

[15] Judge, T. A., Scott, B. A., \& Ilies, R., Hostility, Job Attitudes, and Workplace Deviance: Test of a Multilevel Model. Journal of Applied Psychology, Vol. 91, No. 1, 126-138, (2006).

[16] Crossman, A., \& Abou-Zaki, B., Job satisfaction and employee performance of Lebanese banking staff. Journal of Managerial Psychology, Vol. 18 Iss: 4, pp.368 - 376, (2003).

[17] Casper, W. J., \& Buffardi, L. C., Work-life benefits and job pursuit intentions: The role of anticipated organizational support. Journal of Vocational Behavior, Vol. 65, Iss. 3, PP.391410, (2004).

[18] Fu, W., \& Deshpande, S. P., Antecedents of Organizational Commitment in a Chinese Construction Company. Journal of Business Ethics, 301-307, (2012).

[19] Hui, C., lee, C., \& Rousseau, D. M., Psychological Contract and Organizational Citizenship in China: Investigating Generalizability and Instrumentality. Journal of Applied Psychology, 311-321, (2004).

[20] Kossek, E. E., Lewis, S., \& Hammer, L. B., Work-life initiatives and organizational change: Overcoming mixed messages to move from the margin to the mainstream. Human Relations, 63(1), PP. 3-19, (2010).

[21] Robbins, S. P., \& Judge, T. A., Organizational behavior 15th Edition. Pearson, (2013).

[22] Perrewé, P. L., Hochwarter, W. A., \& Kiewitz, C., Value attainment: An explanation for the negative effects of work-family conflict on job and life satisfaction. Journal of Occupational Health Psychology, Vol 4(4), pp. 318-326, (1999).

[23] Virick, M., Lilly, J. D., \& Casper, W. J., Doing more with less An analysis of work life balance among layoff survivors. Career Development International, Vol. 12 No. 5, pp. 463-480, (2007).

[24] Hughes, J., \& Bozionelos, N., Work-life balance as source of job dissatisfaction and withdrawal attitudes; An exploratory study on the views of male workers. Personnel Review, Vol. 36 No. 1, pp. 145-154, (2007).

[25] Anderson, S. E., Coffey, B. S., \& Byerly, R. T., Formal organizational initiatives and informal workplace practices: links to work-family conflicts and job-related outcomes. Journal of Management, Vol. 28 No. 6, pp. 787-810, (2002).

[26] Burke, R. J., \& Greenglass, E. R., Work-family conflict, spouse support, and nursing staff well-being during organizational restructuring. Journal of Occupational Health Psychology, Vol 4(4), pp. 327-336, (1999). 
[27] Gachter, M., Savage, D. A., \& Torgler, B., Retaining the thin blue line: What shapes workers' intentions not to quit the current work environment. International Journal of Social Economics , 479-503, (2013).

[28] Green, A. E., Miller, E. A., \& Aarons, G. A., Transformational Leadership Moderates the Relationship Between Emotional Exhaustion and Turnover Intention Among Community Mental Health Providers. Community Mental Health Journal , 49:373-379, (2013).

[29] Demirtas, O., \& Akdogan, A. A., The Effect of Ethical Leadership Behavior on Ethical Climate, Turnover Intention, and Affective Commitment. Journal of Business Ethics, (2014).

[30] Chen, J., Wang, L., \& Tang, N., HALF THE SKY: The Moderating Role of Cultural Collectivism in Job Turnover Among Chinese Female Workers. Journal of Businesss Ethics, (2014).

[31] Suazo, M. M., The mediating role of psychological contract violation on the relations between psychological contract breach and work-related attitudes and behaviors. Journal of Managerial Psychology, 136-160, (2009).

[32] Lacity, M. C., Iyer, V. V., \& Rudramuniyaiah, P. S., Turnover intentions of Indian IS professionals. Information Systems Frontiers , 225-241, (2008).

[33] Christian, J. S., \& Ellis, A. P., The Crucial Role of Turnover Intentions in Transforming Moral Disengagement Into Deviant Behavior at Work. Journal of Business Ethics , 193-208, (2014).

[34] Bonenberger, M., Aikins, M., Akweongo, P., \& Wyss, K., The effects of health worker motivation and job satisfaction on turnover intention in Ghana: a cross-sectional study. Human Resources for Health, (2014).

[35] Mulki, J. P., Jaramillo, J. F., \& Locander, W. B., Effect of Ethical Climate on Turnover Intention: Linking Attitudinal- and Stress Theory. Journal of Business Ethics , 559-574, (2008).

[36] Chen, H.-C., Chu, C.-I., Wang, Y.-H., \& Lin, L.C., Turnover factors revisited: A longitudinal study of Taiwan-based staff nurses. International Journal of Nursing Studies, Volume 45, Issue 2. pp. 277-285, (2008).

[37] Farrell, D., \& Rusbult, C. E., Exchange variables as predictors of job satisfaction, job commitment, and turnover: The impact of rewards, costs, alternatives, and investments. Organizational Behavior and Human Performance, Vol. 28, Iss. 1, PP. 78-95, (1981).

[38] Meyer, J. P., \& Allen, N. J., A three component conceptualization of organizational commitment. Human Resource Management Review , 61-98, (1991).

[39] Law, D. W., Interactive organizational commitment and hardiness in public accountants' turnover. Managerial Auditing Journal, Vol. 20 Iss: 4, pp.383 - 393, (2005).

[40] Perryer, C., Jordan, C., Firns, I., \& Travaglione, A., Predicting turnover intentions: The interactive effects of organizational commitment and perceived organizational support. Management Research Review, Vol. 33 Iss: 9, pp.911 - 923, (2010).

[41] Huang, T. C., Lawler, J., \& Lei, C.-Y., The effects of quality of work life on commitment and turnover intention. Social Behavior and Personality, 35, 735-750, (2007).

[42] Colarelli, S. M., Methods of communication and mediating processes in realistic job previews. Journal of Applied Psychology, 633-642, (1984). 
[43] Fu, W., Deshpande, S. P., \& Zhao, X., The Impact of Ethical Behavior and Facets of Job Satisfaction on Organizational Commitment of Chinese Employees. Journal of Business Ethics , 537-543, (2011).

[44] Jaros, S. J., Jermier, J. M., Koehler, J. W., \& Sincich, T., Effects of continuance, affective, and moral commitment on the withdrawal process: An evaluation of eight structural equation models. Academy of Management Journal, Vol. 36, No. 5, PP.951-995, (1993).

[45] Baron, R. M., \& Kenny, D. A., The moderator-mediator variable distinction in social psychological research: conceptual, strategic, and statistical considerations. Journal of Personality and Social Psychology, Vol 51(6), PP. 1173-1182, (1986). 